\title{
Silica Nanocapsules with Different Sizes and Physicochemical Properties as Suitable Nanocarriers for Uptake in T-Cells
}

This article was published in the following Dove Press journal: International Journal of Nanomedicine

\author{
Raweewan Thiramanas $\mathbb{D}^{1,2, *}$ \\ Shuai Jiang ${ }^{2, *}$ \\ Johanna Simon ${ }^{1,2}$ \\ Katharina Landfester (D ${ }^{2}$ \\ Volker Mailänder (iD) 1,2 \\ 'Dermatology Clinic, University Medical \\ Center of the Johannes Gutenberg- \\ University Mainz, Mainz 55I3I, Germany; \\ ${ }^{2}$ Physical Chemistry of Polymers, Max \\ Planck Institute for Polymer Research, \\ Mainz, 55।28, Germany
}

*These authors contributed equally to this work
Correspondence: Katharina Landfester; Volker Mailänder

Email landfest@mpip-mainz.mpg.de; mailaend@mpip-mainz.mpg.de
Introduction: Adoptive T-cell immunotherapy emerged as a powerful and promising cancer therapy, as the problem regarding the immuno-reaction between different donors and recipients can be avoided. However, this approach is challenging. After long cultivation and expansion under laboratory media conditions, T-cells are losing their viability and function due to immune checkpoint proteins, leading to decreased efficiency in killing cancer cells. Therefore, a new strategy to improve T-cell survival and function is needed. With the advantages of nanotechnology and the biocompatibility of silica-based material, silica nanocapsules (SiNCs) provide an ideal delivery system to transport therapeutic biomolecules to T-cells. Up to now, there is a lack of cellular uptake studies of nanocarriers towards T-cells.

Methods: We systematically studied the influence of various physicochemical properties such as sizes, core hydrophobicities, surface charges, and surface functionalities of SiNC for their impact on cellular uptake and toxicity in $\mathrm{CD} 8^{+} \mathrm{T}$-cells by flow cytometry and confocal laser scanning microscopy. Cytokine secretion assay was performed using the enzyme-linked immunosorbent assay. To identify suitable uptake conditions for SiNCs into $\mathrm{CD} 8^{+} \mathrm{T}$-cells, the impact of human serum in cell culture medium was also investigated.

Results: The major impact on cellular uptake and toxicity was found to be size- and dosedependent. Smaller sizes of SiNCs than $100 \mathrm{~nm}$ caused significant toxicity to the cells. It was found that the formed protein corona reduced the toxicity of the SiNCs. However, it also inhibited their uptake.

Conclusion: Overall, we present a set of different criteria for a suitable design of nanocarriers and cell culture conditions, which need to be carefully considered for T-cell immunotherapy in vitro to facilitate uptake while avoiding toxicity.

Keywords: silica nanocapsule, T-cells, nanocarriers, cellular uptake, toxicity, protein corona

\section{Introduction}

Adoptive T-cell immunotherapy (ACT) is the new era of cancer therapy. It can be used to destroy cancer cells by using the immune cells from the patients themselves. ${ }^{1}$ Compared to traditional cancer therapies including surgery, chemotherapy and radiation therapy, immunotherapy has several distinct advantages including no immune reaction due to the fact that donor and recipient are the same person, high specificity, and high cancer-killing ability due to intrinsic functionalities of $\mathrm{CD}^{+}$T-cells, which are able to recognize and destroy cancer cells. ${ }^{2}$ Therefore, $\mathrm{CD}^{+}$T-cells are also termed as cytotoxic T-cells. CD4+ T-cells support 
the other cells in the immune system and especially $\mathrm{CD} 8^{+}$ T-cells as well as B-cells. It was mentioned that immunotherapy may overcome the problem of tumor recurrence after surgery and also defeat late-stage cancer, which has very limited options in terms of traditional cancer therapies. ${ }^{2}$ However, the problem of this technique is that after several rounds of expansion the immune cells have intrinsic mechanisms to shut off the immune reaction. After a certain time of activation, the expression of immune checkpoint proteins from either dendritic cells or T-cells themselves will be induced, causing T-cell inactivation and leading to a loss of T-cell survival and function. ${ }^{3-5}$ This situation also occurs in T-cell cultivation for immunotherapy after collection from the patient and activating the T-cells in culture media, resulting in decreased efficacy for cancer treatment. ${ }^{3-5}$ With significant achievements in ACT and a promising cancer therapy, research focused on the improvement of T-cell survival and function has been intensively pursued and reported. ${ }^{1,2,4,5}$ A wide range of therapeutic agents have been used to boost immunity including vaccines, ${ }^{6}$ monoclonal antibodies, ${ }^{7}$ cytokines, ${ }^{8,9}$ siRNAs specific-immune checkpoint proteins such as cytotoxic $\mathrm{T}$ lymphocyteassociated molecule 4 (CTLA-4), ${ }^{10}$ Casitas B-lineage lymphoma $\mathrm{b}$ (Cbl-b), ${ }^{11}$ programmed cell death-1 (PD-1), ${ }^{12}$ and their ligands (PD-L1/PD-L2). ${ }^{13}$ To achieve this goal, an efficient delivery system loaded with specific biomolecules such as drugs, nucleotides, peptides, proteins, and fluorescent dyes is needed in order to obtain the biological effect or track the carrier.

The criteria for an ideal delivery system require the abilities to protect the payload against the cell culture environment and the low $\mathrm{pH}$ value in endosomes/lysosomes. Internalization into the cell without toxicity and without immune response initiation as well as subsequent release of the payload, which is still able to function inside the cell, is also required. ${ }^{14}$ Due to the rapid development of nanotechnology, a variety of nanocarriers have been designed and widely applied in various fields, especially for biomedical applications. ${ }^{15}$ Nano-sized carriers provide high surface to volume ratio, protect cargo from the biological environment before encountering the target cell, and facilitate uptake. Among them, silica nanocapsules (SiNCs) have many advantages including high loading capacity, excellent colloidal and chemical stability, biocompatibility and biodegradability. ${ }^{16}$ With their outstanding properties, silica-based nanocapsules (SiNCs) have been used for drug delivery. ${ }^{16,17}$ SiNCs are not only easy to synthesize in various well-defined controllable sizes, but also facile to modify for different surface functionalities through the rich hydroxyl groups on their surface. Moreover, silicon oxide has been accepted by the US Food and Drug Administration (USFDA) for use in food additives as well as medical care products. ${ }^{16,17}$ Thus, SiNCs seem to be suitable for use as alternative nanocarriers in T-cells treatment.

T-cells have no high capacity for uptake of foreign particles as their main function is not sampling of the surrounding like it is the case for other immune cells like dendritic cells. They are also highly sensitive to the cell culture environment. ${ }^{18}$ Few uptake studies of silica nanomaterials in T-cells or related-cells have been reported. Silica nanoparticles (SiNPs) were found to induce oxidative stress and the inflammation of human peripheral blood mononuclear cells (PBMCs). Notably, smaller-sized SiNPs with $10 \mathrm{~nm}$ were more cytotoxic and induced more oxidative stress than the bigger SiNPs with $100 \mathrm{~nm} .{ }^{19}$ In addition, ultra-small SiNPs $(<10 \mathrm{~nm})$ were also found to cause T-cell activation by increasing the expression of CD25 and CD69 and the secretion of IFN $-\gamma^{20}$ The toxicity of SiNPs was found to be strongly related to their physicochemical properties, such as size, surface area, and surface features. ${ }^{21}$ Due to the lack of systematic study in terms of various physicochemical parameters of the silica nanocarriers uptake in T-cell, a better understanding is required concerning the critical properties of SiNC, which affect T-cell uptake prior to use of SiNC as a carrier for T-cell immunotherapy.

This study aims to investigate the crucial parameters including the size, core hydrophobicity, surface charge, and functionalization of the SiNCs affecting cellular uptake in $\mathrm{CD} 8^{+} \mathrm{T}$-cells. For this purpose, novel silica coreshell nanocapsules were synthesized. In general, the therapeutic payload is encapsulated in the SiNC cavity. Here, we used a new one-pot synthesis to facilely incorporate the payload into the core surrounded with silica shell, which can be beneficial to protect the cargo inside the silica shell. It also provides a high loading capacity for the cargo. To avoid interfering with its surface properties, the fluorescent dye Cy 5 was covalently incorporated into the shell by using fluorescently labeled silica precursors, which allowed tracking of the capsules inside the cell by flow cytometry and confocal laser scanning microscopy (cLSM). Considering in vivo uptake for systemic administration, once the nanocarrier faces the biological fluid, the biomolecular components, e.g., blood proteins attract to the carrier surface then create a new identity known as 
protein corona. The protein corona finally impacts cellular uptake. $^{22}$ Therefore, the effect of protein corona formation on the cellular uptake in $\mathrm{CD} 8^{+}$T-cells was investigated. The uptake and toxicity of human serum pre-coated SiNCs compared to the uncoated ones were analyzed by flow cytometry. The hard protein corona was investigated by SDS-PAGE and could subsequently be identified by liquid chromatography-mass spectrometry (LC-MS). A better understanding of the consequences of different physicochemical parameters for SiNCs on cellular uptake in $\mathrm{CD}^{+}$ T-cells provides information to carefully consider designing the SiNCs for T-cell immunotherapy.

\section{Materials and Methods}

\section{Synthesis of Silica Nanocapsules}

Silica nanocapsules were synthesized in an oil-in-water miniemulsion by using the surface of oil nanodroplets as template for the hydrolysis and condensation of alkoxysilanes. Specifically, $2.0 \mathrm{~g}(9.6 \mathrm{mmol})$ of TEOS was first mixed with $125 \mathrm{mg}$ of hexadecane and $1 \mathrm{~g}$ of organic solvent (olive oil or chloroform) to form the oil phase for the synthesis of NCs with hydrodynamic diameter of $\sim 150 \mathrm{~nm}$. In order to tune the size of NCs, $400 \mathrm{vol} \%, 200$ vol $\%, 50$ vol $\%$, or 25 vol $\%$ of the above solution was used as oil phase. In the second step, $30 \mathrm{~mL}$ of $0.77 \mathrm{mg} / \mathrm{mL}$ aqueous solution of CTMA-Cl was poured into the oil mixture under stirring. After a pre-emulsification step by stirring at $1000 \mathrm{rpm}$ for $1 \mathrm{~h}$, the obtained emulsion was sonicated by using a Branson $450 \mathrm{~W}$ sonifier with a $1 / 2$ "

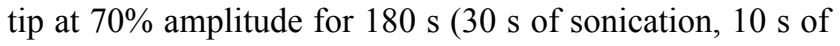
pause) with ice cooling. The resulting miniemulsion was stirred at $1000 \mathrm{rpm}$ for $12 \mathrm{~h}$ at room temperature to obtain an aqueous dispersion of SiNCs. The SiNCs containing olive oil are denoted as hydrophobic SiNCs. In the case of nanocapsules containing chloroform as core liquid, the dispersion was further stirred at air for $24 \mathrm{~h}$ to evaporate the chloroform, during which the water diffuses in for filling the core to obtain hydrophilic SiNCs.

To obtain NCs stabilized with nonionic surfactant Lutensol AT50, $40 \mathrm{mg}$ of Lutensol AT50 was added to $2 \mathrm{~mL}$ of $\mathrm{NC}$ dispersion. The mixture was stirred at $1000 \mathrm{rpm}$ for $2 \mathrm{~h}$ and then dialyzed against water within a dialysis tube with MWCO of $1000 \mathrm{~g} / \mathrm{mol}$. In this case, CTMA-Cl $\left(M_{\mathrm{w}}=320 \mathrm{~g} / \mathrm{mol}\right)$ could diffuse through the dialysis membrane into the aqueous dialysis medium while Lutensol AT50 $\left(M_{\mathrm{w}}=2460 \mathrm{~g} / \mathrm{mol}\right)$ was kept inside.
For amino functionalization of SiNCs, $0.5 \mathrm{~mL}$ dispersion of SiNC-LUT was first diluted by $2 \mathrm{~mL}$ of $0.1 \mathrm{vol} \%$ acetic acid solution. The calculated amount of APTES ( $1 \mathrm{wt} \%$ in acetic acid solution, $\mathrm{pH} \sim 3.5$ ) was added to the dispersion. Afterward, the dispersion was stirred at $50{ }^{\circ} \mathrm{C}$ for 2 days. The samples were then purified by washing with $0.3 \mathrm{wt} \%$ Lutensol aqueous solution two times by centrifugation. For fluorescent labeling of SiNCs, Cy5NHS was first coupled with APTES at a molar ratio of 1:1.1 to obtain fluorescently labeled silica precursors. The APTES-Cy5 conjugates were then mixed with TEOS as the silica source. The molar ratio of fluorescent molecules with TEOS was $1: 14,000$. The synthesized SiNCs were stored at $4{ }^{\circ} \mathrm{C}$ for further tests.

\section{Characterization of Silica Nanocapsules}

Hydrodynamic diameter of silica nanocapsules was measured by using dynamic light scattering (DLS) with a Nicomp particle sizer (Model 380, PSS, Santa Barbara, CA) at a fixed scattering angle of $90^{\circ}$. Zeta potential measurements were performed in $10^{-3} \mathrm{M}$ potassium chloride solution at $25{ }^{\circ} \mathrm{C}$ with a Malvern Zeta sizer (Malvern Instruments, UK). Average results of three measurements were reported. The morphology of nanocapsules was examined with a Jeol 1400 (Jeol Ltd, Tokyo, Japan) transmission electron microscope operating at an accelerating voltage of $120 \mathrm{kV}$. TEM samples of nanocapsules were prepared by casting the diluted dispersions on carbon layer-coated copper grids.

\section{Cell Culture}

Human blood was taken at the Department of Transfusion Medicine Mainz from healthy donors after physical examination and after obtaining written informed consent in accordance with the Declaration of Helsinki. The study was approved by the local ethics committee "Landesärztekammer Rheinland-Pfalz" (Bearbeitungsnummer: 837.439 .12 (8540F)). Peripheral blood mononuclear cells (PBMCs) separation from blood was performed by using lymphocyte separation medium (Histopaque ${ }^{\circledR}-1077, \quad$ Sigma-Aldrich, USA). According to T-cell activation, in vitro protocol from eBioscience, immobilized $0.1 \mu \mathrm{g} / \mathrm{mL}$ of anti-human CD3 (Clone OKT3, functional grade, eBioscience, Germany) and $100 \mathrm{U} / \mathrm{mL}$ recombinant human IL-2 (Novartis, Switzerland) were used to stimulate human PBMCs. The cells were grown in Roswell Park Memorial Institute (RPMI, Gibco, USA) complete medium containing $10 \%$ fetal bovine serum (FBS, Gibco, USA), 1\% L-Glutamine (Gibco, USA) and 1\% penicillin/streptomycin (Gibco, USA). $\mathrm{CD}^{+}$T-cells were 
separated from the culture after cell clumping was found on the bottom of the flask. CD8 MicroBeads were used to harvest the specific $\mathrm{CD}^{+}$T-cells and bound to immunomagnetically MACS separation column (Miltenyi Biotec, Germany). After elution, $\mathrm{CD}^{+}$T-cells were restimulated with anti-CD3 and IL2 in RPMI complete medium as described above and incubated at $37^{\circ} \mathrm{C}$ in $\mathrm{CO}_{2}$-incubator with $95 \%$ humidity and $5 \% \mathrm{CO}_{2}$ (C200, Labotect, Germany). To collect the cell, the cell culture was centrifuged at $500 \mathrm{~g}$ for $5 \mathrm{~min}$, resuspended in RPMI medium and used for subsequent experiment. Viable cells were distinguished by trypan blue exclusion method and recorded by using $\mathrm{TC} 10^{\mathrm{TM}}$ automated cell counter (Bio-Rad, USA).

\section{Cellular Uptake Study by Flow Cytometry}

To study for cellular uptake, $\mathrm{CD}^{+} \mathrm{T}$-cells resuspended in RPMI medium containing $1 \% \mathrm{FBS}$ and $100 \mathrm{U} / \mathrm{mL}$ IL-2 without antibiotics were added into $0.1 \mu \mathrm{g} / \mathrm{mL}$ of anti-CD3 immobilized 24-well plate at a density of 200,000 cells per well. Then, various concentrations of SiNCs were incubated with the cells for $24 \mathrm{~h}$. After that, the cells were washed and resuspended in PBS. Flow cytometry measurements were performed on a Attune ${ }^{\mathrm{TM}} \mathrm{NxT}$ Flow Cytometer (Invitrogen, USA). Zombie Aqua ${ }^{\mathrm{TM}}$ dye (BioLegend, USA) was used for live cell gating with the excitation of the violet laser (405 $\mathrm{nm}$ ) and detected in channel VL-2. Cy5 dye labeling SiNCs is excited with red laser $(638 \mathrm{~nm})$ and recorded in channel RL-1. The cells that supposed to take up the SiNCs containing Cy5 dye were presented as Cy5 positive-cells. Data analysis was performed using Attune ${ }^{\mathrm{TM}} \mathrm{NxT}$ software (Invitrogen, USA) by selecting the cells on a forward/sideward scatter plot, thereby excluding cell debris. These gated events were shown by the histogram of fluorescent signal. Percentages of cell viability were recorded from living cells (Zombie Aqua negative-cells) compared to dead cells (Zombie Aqua positive-cells). After gating for living cells, percentages of Cy5 positive-cells were reported.

\section{Cell Imaging by Confocal Laser Scanning Microscopy (cLSM)}

To confirm for cellular uptake, $\mathrm{CD}^{+} \mathrm{T}$-cells resuspended in RPMI medium containing $1 \%$ FBS and $100 \mathrm{U} / \mathrm{mL}$ IL-2 without antibiotics were added into $0.1 \mu \mathrm{g} / \mathrm{mL}$ of anti-CD3 immobilized 24-well plate at a density of 200,000 cells per well. Then, the cells were incubated with $20 \mu \mathrm{g} / \mathrm{mL}$ of SiNCs for $24 \mathrm{~h}$. After that, the cells were washed and transferred to
$\mu$-Slide 8 well with a glass coverslip bottom (Ibidi, Germany). Live cell images were taken with a commercial setup (LSM SP5 STED Leica Laser Scanning Confocal Microscope, Leica, Germany), consisting of an inverse fluorescence microscope DMI 6000 CS equipped with a multilaser combination, five detectors operating in the range of 400-800 nm. A HCX PL APO CS 63 x 1.4 oil objective was used in this study. The excitation and detection conditions in a sequential mode were described as follows: fluorescent nanocapsules containing $\mathrm{Cy} 5$ dye were excited with $\mathrm{HeNe}$ laser $(633 \mathrm{~nm})$, detected at $650-710 \mathrm{~nm}$ and pseudocolored in green. The cell membrane was stained with CellMask ${ }^{\mathrm{TM}}$ Orange $(5 \mu \mathrm{g} / \mathrm{mL}$, Life technologies, USA), excited with a DPSS laser $(561 \mathrm{~nm})$, detected at 570-600 $\mathrm{nm}$, pseudocolored in red.

To provide more evidence for cellular uptake, colocalization assay of SiNC and lysosome was investigated. After SiNCs was added to $\mathrm{CD}^{+}$T-cells as mentioned above, the cells were washed and transferred to the $\mu-$ Slide 8 well. LysoTracker ${ }^{\circledR}$ Green DND-26 (50 nM diluted in DMEM, Life Technologies, USA) was used to stain lysosomes for $1 \mathrm{~h}$, excited with an Ar laser (488 nm), detected at 510-540 $\mathrm{nm}$ and pseudocolored in (red). The membrane was stained with CellMask ${ }^{\mathrm{TM}_{\mathrm{M}}}$ Orange and pseudocolored in blue. The SiNC was labeled with Cy5 and pseudocolored in green. The merged images of three channels demonstrated that SiNCs encapsulated Cy5 were colocalized with lysosomes as indicated with white arrows.

To study for cellular uptake progressing process, Jurkat T-cells (ACC 282) were obtained from DSMZ (Deutsche Sammlung von Mikroorganismen und Zellkulturen, Germany). We generated a master cell bank from the vial obtained. Then, every 3 months the old cell lines were discarded and a new vial from the master cell bank was thawed. Old and new batches of cells were tested for mycoplasma. Jurkat T-cells were resuspended in RPMI medium containing $10 \%$ FBS. Then, they were seeded in a 96-well round-bottom plate at a density of 100,000 cells per well. The cells were incubated with $75 \mu \mathrm{g} / \mathrm{mL}$ of NC(o)-LUT and cellular uptake progress was tracked at 2, 4, 24 and $48 \mathrm{~h}$ by taking cLSM images as described above.

\section{Protein Corona Effect on Cellular Uptake}

To study the effect of protein corona on cellular uptake, SiNCs were pre-incubated with human serum prior to incubation with $\mathrm{CD}^{+}$T-cells. Human serum was thawed and centrifuged at $20,000 \mathrm{~g}$ under $4{ }^{\circ} \mathrm{C}$ for $30 \mathrm{~min}$. The supernatant $(1 \mathrm{~mL})$ was transferred to a new $1.5 \mathrm{~mL}$-Protein 
LoBind tube (Eppendorf, Germany) containing calculated volume of SiNC solution with the amount of capsule that provide a surface area of $0.05 \mathrm{~m}^{2}$ per reaction according to the following equations (1-3).

$$
\begin{gathered}
V_{\text {dispersion for } 0.05 m^{2} N C \text { surface }} \\
=\frac{N_{N C} \cdot m_{\text {dry NC }}}{\rho_{\text {dispersion }} \cdot \text { Solid content }(w t \%)} \\
N_{N C}=\frac{0.05 m^{2}}{S_{N C}}=\frac{0.05 m^{2}}{4 \pi r^{2}} \\
m_{d r y ~ N C}=m_{H D}+m_{S i O 2}=m_{H D}+\frac{M w_{\text {SiO } 2}}{M w_{T E O S}} \cdot m_{T E O S} \\
=\rho_{H D} \cdot V_{H D}+\frac{M w_{S i O 2}}{M w_{T E O S}} \rho_{T E O S} V_{T E O S} \\
=\rho_{H D} \cdot V_{d r o p l e t} \cdot \frac{V_{H D}}{V_{T E O S}+V_{H D}+V_{C H C l 3}} \\
+\frac{M w_{S i O 2}}{M w_{T E O S}} \rho_{T E O S} V_{d r o p l e t} \cdot \frac{V_{T E O S}}{V_{T E O S}+V_{H D}+V_{C H C l 3}}
\end{gathered}
$$

where $N_{N C}$ is the number of NCs in the dispersion, $m_{d r y} N C$ is the mass of single $\mathrm{NC}$ at dried state, $\rho_{\text {dispersion }}$ is the density of NC dispersion, and $S_{N C}$ is the surface area per NC.

The SiNC-serum mixture was incubated at $37^{\circ} \mathrm{C}$ for $1 \mathrm{~h}$ with $300 \mathrm{rpm}$ shaking in ThermoMixer (HLC Heating, MHR 23, DITABIS, Germany). After that, hard corona SiNCs were separated by centrifugation $(20,000 \mathrm{~g})$ at $4{ }^{\circ} \mathrm{C}$ for $1 \mathrm{~h}$ and resuspended in $1 \mathrm{~mL}$ PBS. The samples were continued to wash 3 times more, resuspended in $1 \mathrm{~mL}$ PBS and finally added to $0.1 \mu \mathrm{g} / \mathrm{mL}$ of anti-CD3 pre-coated 24-well plate containing 200,000 cells per well of $\mathrm{CD}^{+}$T-cells resuspended in RPMI medium containing $100 \mathrm{U} / \mathrm{mL}$ IL-2 without antibiotics in the presence of different concentrations of human serum at $0 \%, 1 \%$ and $10 \%$. To keep the cells in a good condition, the human serum was added to the group of $0 \%$ to obtain $1 \%$ final concentration after $6 \mathrm{~h}$. The uptake of uncoated SiNC in the presence of $1 \%$ FBS was used to compare with the pre-coated SiNCs uptake in the presence of $0 \%, 1 \%$ and $10 \%$ human serum. After $24 \mathrm{~h}$ of incubation, the cells were collected and determined for cell viability and Cy 5 positive-cells by flow cytometer as described above.

\section{Protein Pattern Analysis by SDS-PAGE}

After separating and 3 times washing of hard corona SiNCs, the capsule pellet was resuspended in $100 \mu \mathrm{L}$ of desorption buffer containing 2\% SDS, $62.5 \mathrm{mM}$ Tris- $\mathrm{HCl}$ and incubated at $95{ }^{\circ} \mathrm{C}$ for $5 \mathrm{~min}$. After centrifugation at $20,000 \mathrm{~g}, 4^{\circ} \mathrm{C}$ for 1 $\mathrm{h}$, the supernatant containing the protein absorbed on the surface of the capsules was collected and kept at $-20{ }^{\circ} \mathrm{C}$ until used. The protein concentration was determined by Pierce $^{\text {TM }}$ 660nm Protein Assay (Pierce, USA) according to the manufacturer's instruction. The total amount of protein at $1.5 \mu \mathrm{g}$ of each sample was loaded onto pre-cast Bolt ${ }^{\mathrm{TM}} 10 \%$ Bis-Tris Plus Gel (Invitrogen, USA) and separated in MES SDS running buffer (Invitrogen, USA) at 100 volts for $1 \mathrm{~h} 15$ min. Then, the gel was stained with SilverQuest ${ }^{\mathrm{TM}}$ Silver Staining Kit (Invitrogen, USA) according to the manufacturer's protocol.

\section{Liquid Chromatography Coupled to Mass Spectrometry (LC-MS) Analysis}

Prior to digestion, SDS was removed from the protein samples via Pierce $^{\mathrm{TM}}$ Detergent Removal Spin Column (Thermo Fisher). Proteins were digested as previously described. ${ }^{23,24}$ Briefly, proteins were precipitated using ProteoExtract protein precipitation kit (Merck Millipore) according to the manufactures' instruction. The protein pellet was resuspended with RapiGest SF (Waters) dissolved in $50 \mathrm{mM}$ ammonium bicarbonate. To reduce disulfide bonds, dithiothreitol ( $5 \mathrm{mM}$, Sigma) was added and samples were incubated at $56{ }^{\circ} \mathrm{C}$ for $45 \mathrm{~min}$. For alkylation, iodoacetamide (15 $\mathrm{mM}$, Sigma) was added for $1 \mathrm{~h}$ in the dark. Tryptic digestion was carried out (protein ratio of $1: 50$ ) overnight at $37{ }^{\circ} \mathrm{C}$ using trypsin (protein ratio of 1:50). The reaction was stopped with $2 \mu \mathrm{L}$ hydrochloric acid.

Peptide samples were diluted with aqueous $0.1 \%$ formic acid and spiked with $50 \mathrm{fmol} / \mu \mathrm{L} \mathrm{Hi3}$ EColi Standard (Waters Corporation) for absolute quantification. A Synapt G2-Si mass spectrometer coupled to a nanoACQUITY UPLC system was used for LC-MS analysis. Therefore, peptides were applied to a C18 nanoACQUITY trap column $(5 \mu \mathrm{m}, 180 \mu \mathrm{m} \times 20 \mathrm{~mm})$ followed by a C18 analytical reversed phase column $(1.7 \mu \mathrm{m}, 75 \mu \mathrm{m} \times 150 \mathrm{~mm})$. A gradient from $2 \%$ to $37 \%$ for solvent A (water with $0.1 \%(\mathrm{v} / \mathrm{v})$ formic acid) to solvent $\mathrm{B}$ (acetonitrile with $0.1 \%(\mathrm{v} / \mathrm{v})$ formic acid) with a flow rate of $0.3 \mu \mathrm{L} \mathrm{min}{ }^{-1}$ was chosen for separation. A reference solution consisting of Glu-Fibrinopeptide (GPF, Sigma) was infused at a flow rate of $0.5 \mu \mathrm{L} \min ^{-1}$. Ionization was performed with a NanoLock Spray source in positive ion mode and dataindependent acquisition $\left(\mathrm{MS}^{\mathrm{E}}\right)$ experiments were performed. The total acquiring time was $90 \mathrm{~min}$ and the mass range was set to $\mathrm{m} / \mathrm{z}$ 50-2000 Da. 
For peptide identification, MassLynx 4.1 and Progenesis QI for proteomics was used. Identified peptides were searched against a reviewed human database downloaded from Uniprot (including the sequence information of Hi3 Ecoli standard). A maximum protein mass of 600 $\mathrm{kDa}$ and false discovery rate of $4 \%$ were defined. In general, for peptide and protein identification the following parameters were set: A minimum of three assigned fragments for peptide identification and for protein identification at least two assigned peptides and five assigned fragments. Via the TOP3/Hi3 approach, the absolute amount of protein in fmol was determined. ${ }^{25}$ The total amount in \% based on all identified proteins was calculated. A full list of all identified proteins can be found in a separate Excel file.

\section{Enzyme-Linked Immunosorbent Assay (ELISA)}

The concentrations of interferon-gamma (IFN- $\gamma$ ), Interleukin2 (IL-2), and tumor necrosis factor-beta (TNF- $\beta$ ) in the culture supernatant of $\mathrm{CD}^{+}$T-cells after treatment with different SiNCs for $24 \mathrm{~h}$ were determined by ELISA kits (Invitrogen for IFN- $\gamma$; eBioscience for IL-2 and TNF- $\beta$ ) according to the manufacturers' instruction.

\section{Statistical Analysis}

Data measurements are presented as mean \pm standard deviation $(\mathrm{n}=3)$. Student's t-tests were performed, and calculated $p$ values were considered to be significant for $* p<0.05, * * p<0.01$ and $* * * p<0.001$.

\section{Results and Discussion}

SiNCs are biocompatible and are therefore a promising material for nanocarriers to improve T-cell survival and function in T-cell immunotherapy. In the following study, we investigated the effect of different characteristics including sizes, surface charges, functional groups, and protein interactions of SiNCs on cellular uptake and toxicity in $\mathrm{CD}^{+} \mathrm{T}$-cells.

\section{The Effect of Size}

In the first step, we studied the size effect of nanocarriers on cellular uptake of T-cells. SiNCs with hydrodynamic diameters ranging from $50 \mathrm{~nm}$ to $400 \mathrm{~nm}$ were synthesized by using a miniemulsion (oil-in-water) polymerization technique. $^{26} \mathrm{~A}$ cationic surfactant cetyltrimethylammonium chloride (CTAC) was used to stabilize the mini-emulsion droplets against coalescence. The second role of CTAC is to serve as a template agent for confined silica condensation at the nanodroplet-water interface via cooperative self-assembly of negatively charged silica species and the cationic CTAC. Therefore, positively charged core-shell nanocapsules were obtained with a liquid core that provides a high loading capacity for therapeutic agents. To compare the effect of different charges, the nonionic surfactant Lutensol AT50 (LUT) was chosen as the second surfactant to generate differently charged core-shell nanocapsules. Here, we developed a facile dialysis process for the surfactant replacement from CTAC to the nonionic surfactant LUT, which has a polyethylene glycol chain as its hydrophilic part. The PEGylated surface could then provide steric stabilization of the nanocapsules. The slightly negative charge of SiNC-LUT is due to the dissociation of silanol groups at $\sim \mathrm{pH} 7$, which is above the isoelectric point of silica $(\sim \mathrm{pH} 2-3) .{ }^{27}$ The size of the nanocapsules was tuned by varying the volume ratio of the oil phase and water phase. NCs with average hydrodynamic diameters ranging from $50 \mathrm{~nm}$ (NC-50) to $400 \mathrm{~nm}$ (NC-400) were synthesized as shown in Table 1 . The obtained NCs were characterized in terms of their physicochemical properties, including hydrodynamic diameter $\left(D_{\mathrm{h}}\right)$ by dynamic light scattering (DLS), surface charge by zeta-potential ( $\zeta$-potential) measurements, as listed in Table 1 and morphology by transmission electron microscopy (TEM, Figure S1 Supporting Information). In a previous study, we have studied the porosity of the SiNCs by nitrogen adsorption-desorption experiments. The silica shell has a BET surface area of $141 \mathrm{~m}^{2} \mathrm{~g}^{-1}$, pore volume of $0.7 \mathrm{~cm}^{3} \mathrm{~g}^{-1}$ and average pore size of $18.6 \mathrm{~nm}$, for which we believe it is the average value of the hollow cavity and shell porosity. ${ }^{26}$ The nitrogen adsorption-desorption isotherm of the SiNCs exhibited a typical IV isotherm with $\mathrm{H} 3$ type hysteresis loops with a relative pressure $\mathrm{P} / \mathrm{P}_{0}$ in the range of $0.5-1.0$.

After $24 \mathrm{~h}$ of incubation in $\mathrm{CD}^{+} \mathrm{T}$-cells, the toxicity and uptake of NCs were determined by using flow cytometry. It was found that the toxicity of the capsules was increased when the size decreased, especially for CTACstabilized SiNCs (Figure 1A). A similar trend was also found previously for other cell types such as A549 (human type II alveolar epithelial), HaCaT (human keratinocyte), THP-1 (human monocyte), NRK-52E (rat kidney epithelial), ${ }^{28}$ HepG2 (human hepatoma), ${ }^{29}$ Langerhans (dendritic cells of the skin), ${ }^{30}$ and EAHY926 (human endothelial), ${ }^{31}$ which were treated with different sized silica nanoparticles (SiNPs). It was shown that the toxicity of SiNPs was strongly related to their physicochemical 
Table I Physicochemical Properties (Hydrodynamic Diameter and Zeta Potential) of Hydrophilic Silica Nanocarriers (NCs) with Different Sizes (50-400 nm) and Surfactants (Cationic and Nonionic)

\begin{tabular}{|c|c|c|c|c|c|c|}
\hline & \multirow[b]{2}{*}{ Surfactant } & \multicolumn{5}{|c|}{ Hydrophilic Core, NC(i) } \\
\hline & & NC-400 & NC-200 & NC-I 50 & NC-I 00 & NC-50 \\
\hline$D_{\mathrm{h}}\left(\mathrm{H}_{2} \mathrm{O}\right) / \mathrm{nm}$ & $\begin{array}{l}\text { CTAC } \\
\text { LUT }\end{array}$ & $\begin{array}{l}395 \pm 232 \\
482 \pm 299\end{array}$ & $\begin{array}{l}190 \pm 83 \\
148 \pm 56\end{array}$ & $\begin{array}{l}144 \pm 45 \\
121 \pm 47\end{array}$ & $\begin{array}{l}99 \pm 40 \\
106 \pm 46\end{array}$ & $\begin{array}{l}42 \pm 18 \\
56 \pm 29\end{array}$ \\
\hline$\zeta$-potential $\left(\mathrm{H}_{2} \mathrm{O}\right) / \mathrm{mV}$ & $\begin{array}{l}\text { CTAC } \\
\text { LUT }\end{array}$ & $\begin{array}{l}-4.4 \pm 0.1 \\
-4.2 \pm 0.2\end{array}$ & $\begin{array}{l}-5.0 \pm 0.3 \\
-6.3 \pm 0.3\end{array}$ & $\begin{array}{l}4.7 \pm 0.2 \\
-4.7 \pm 1.0\end{array}$ & $\begin{array}{l}8.8 \pm 0.1 \\
-3.5 \pm 2.5\end{array}$ & $\begin{array}{l}21.5 \pm 2.3 \\
-11.2 \pm 1.6\end{array}$ \\
\hline
\end{tabular}

properties such as size, surface area, and surface features. $^{21,32-35}$ If there are some features associated with toxicity on the surface, smaller size SiNCs provide more surface area as well as more surface reactivity and higher number of particles per mass, resulting in an increased toxicity compared to the larger size particles. ${ }^{28,35,36}$

The mechanism of SiNP-induced toxicity is still not fully elucidated, but it is believed to be derived from reactive oxygen species (ROS)-mediated toxicity. ${ }^{17,32,37}$ Murugadoss et al observed that SiNPs could cause overproduction of ROS resulting in oxidative stress, which could possibly damage the sub-cellular organelles and induce apoptosis in a size- and dose-dependent manner. ${ }^{17}$ In addition, the higher surface area of small SiNCs can lead to a higher possibility to interact with cellular biomolecules such as proteins, sugars and DNA/RNA. ${ }^{34}$ Moreover, small sized NPs may cause toxicity as they can pass through the cell membrane easier and enter the cells faster resulting in higher uptake hereby, facing cellular components or accumulating in subcellular organelles like mitochondria and nucleus. $^{33,34,38}$ Another mechanism of small NP higher uptake-induced toxicity is the actin cytoskeleton disruption, leading to cell deformation and direct cellular injury. ${ }^{33,34,38}$ Since the size of SiNCs was the critical point to induce the cytotoxic effect, the SiNC size was attempted to be controlled at sizes larger than $100 \mathrm{~nm}$ for subsequent experiments to avoid toxicity due to the smaller size.

SiNCs with smaller sizes were found to not only be highly toxic, but also have been taken up less by the cells (Figure 1B). ${ }^{39}$ Therefore, small-sized SiNCs were not further used in this study due to their toxicity. Cellular uptake of SiNCs (NC-400, NC-200 and NC-150) was further confirmed by cLSM (Figure 1C). Green dots representing Cy5 labeled-SiNCs were observed inside the cells, indicating efficient cellular uptake. Moreover, the aggregation or clumping pattern of T-cells treated with LUTstabilized SiNCs was observed indicating healthy cells or the proliferation stage of the cells, which was emphasized by the excellent biocompatibility of LUT-stabilized SiNCs. The result was compared with hydrophobic $\mathrm{Cy} 5$ dye (free dye) treated cells to prove that all the results from Cy5covalently functionalized SiNCs in this study were obtained from the dye labeled capsules and not from free dye (Figure S2, Supporting Information). In addition, we monitored the intracellular fate of the NC-400 exemplary. A co-localization assay of NC-400 with lysosome was also investigated (Figure 1D). The cLSM images showed that the SiNC-Cy5 (green dots) were co-localized with lysosomes (red dots) after $24 \mathrm{~h}$ of incubation. In the overlay, these appeared as yellow dots, as indicated with white arrows. This is a clear indication of cellular uptake.

\section{The Effect of Core Hydrophobicity and Surface Charges}

In the second step, we studied the effect of core hydrophobicity and surface charges of nanocarriers on their cellular uptake in $\mathrm{CD}^{+}$T-cells. Nanocapsules containing olive oil and water as core materials were synthesized as representative hydrophobic ( $\mathrm{NC}(\mathrm{o})$ ) and hydrophilic (NC(i)) core NCs, which can be used to carry oil-soluble and water-soluble therapeutic agents to T-cells, respectively. These NCs are stabilized with CTAC and LUT, as characterized and listed in Table 2.

Hydrodynamic diameters $\left(D_{\mathrm{h}}\right)$ of NC(o) and NC(i) before and after the surfactant exchange were comparable. After amino functionalization with increased densities of amino groups, the zeta potential of NCs increased due to the deprotonated amino groups. The SiNCs stabilized with CTAC exhibited positive surface charge as presented in positive $\zeta$ potential values (NC(o)-CTAC: $12.2 \pm 0.5 \mathrm{mV}$ and $\mathrm{NC}(\mathrm{i})$ CTAC: $13.0 \pm 0.2 \mathrm{mV}$ ) due to the cationic surfactant. LUT is a non-ionic surfactant as well as Tween 20 and Tween 80 . In general, LUT stabilized NCs have nearly neutral surface charge, as found in $\mathrm{NC}(\mathrm{o})$-LUT $(0.05 \pm 0.02 \mathrm{mV})$. Due to 


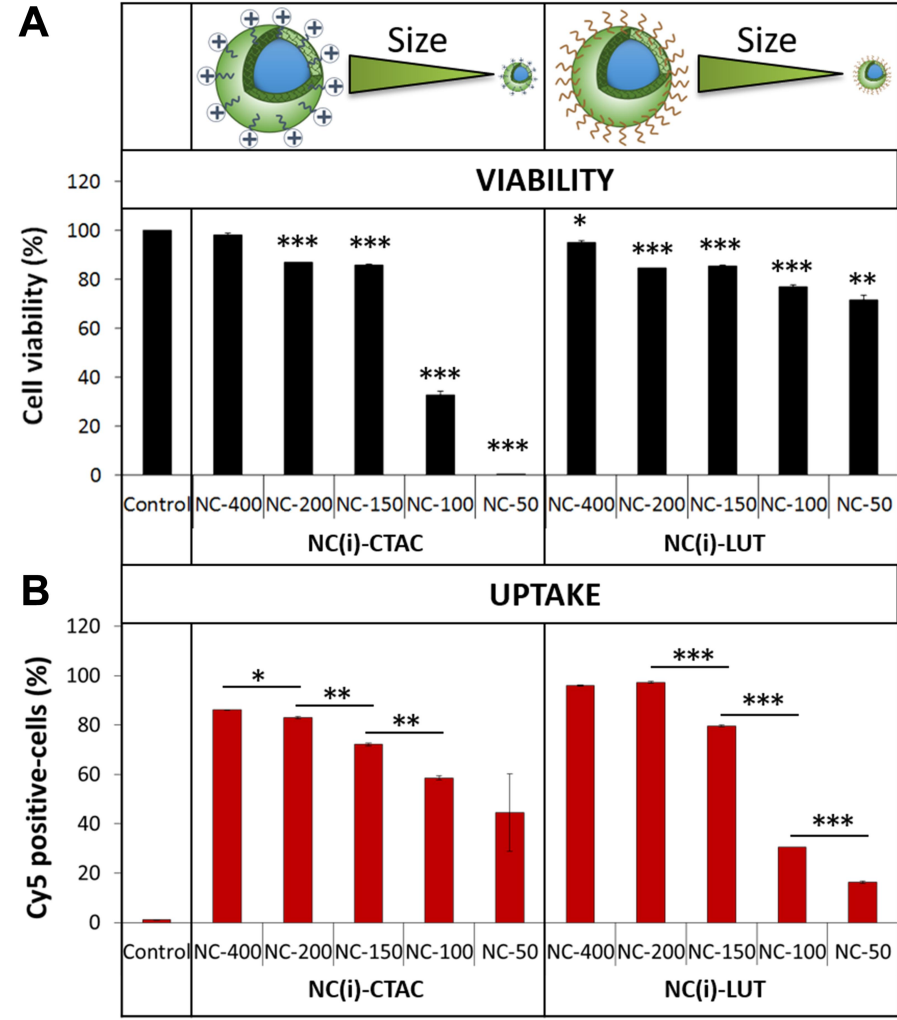

D

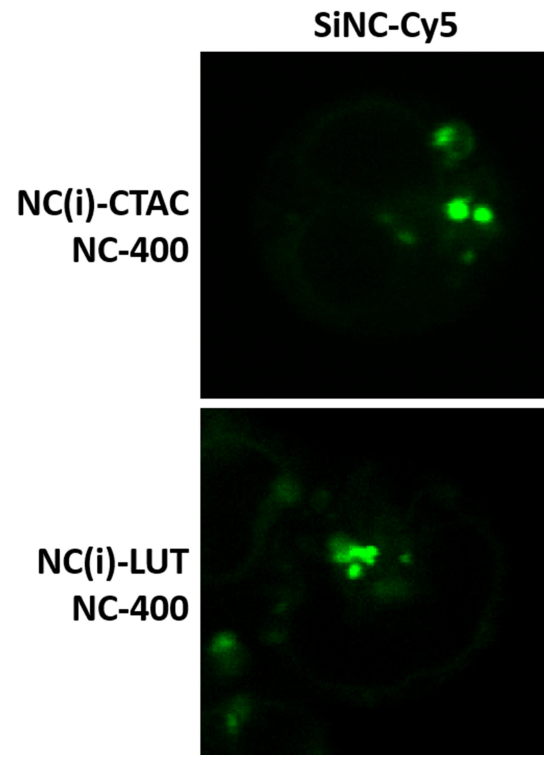

C
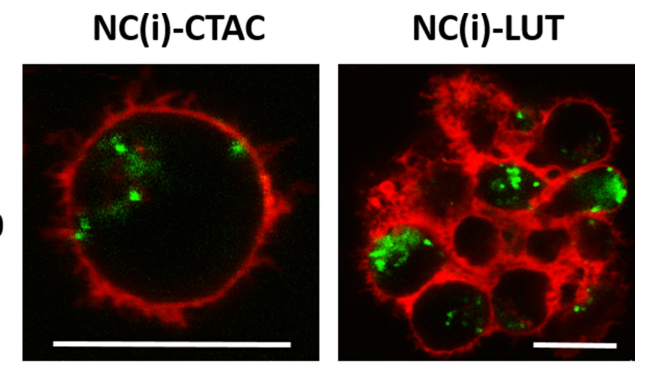

NC-200
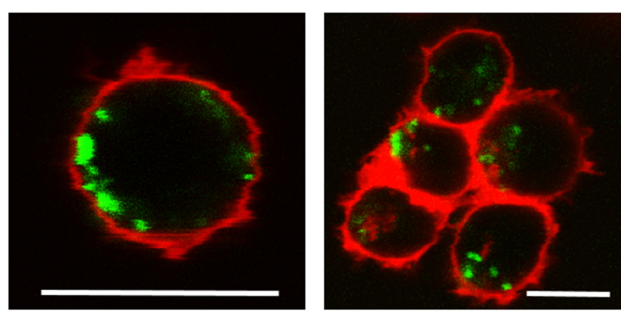

NC-150
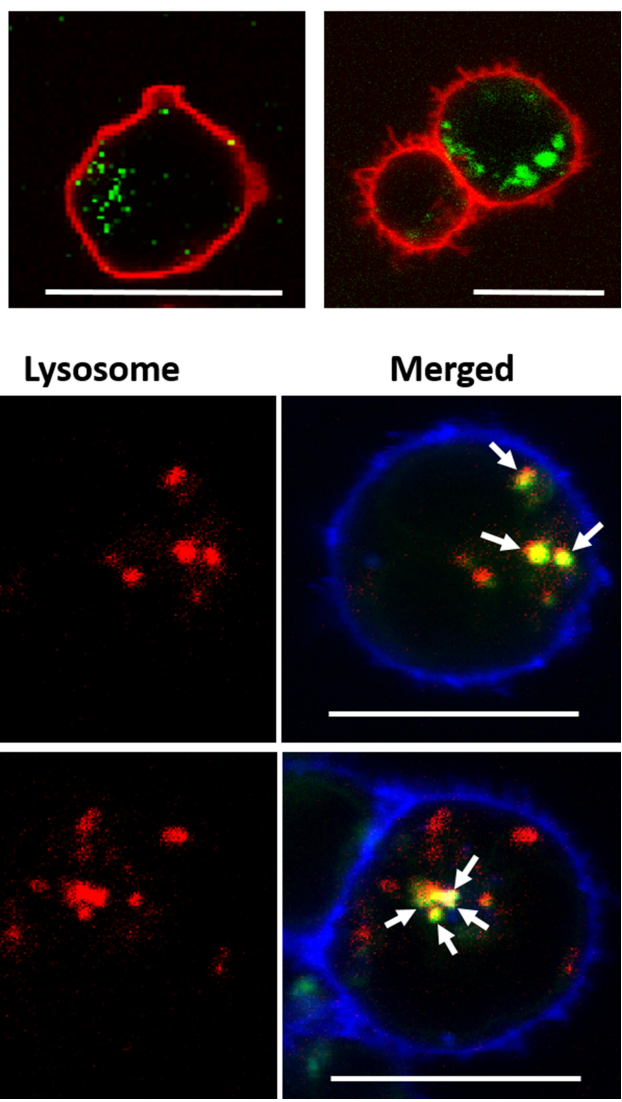

Lysosome

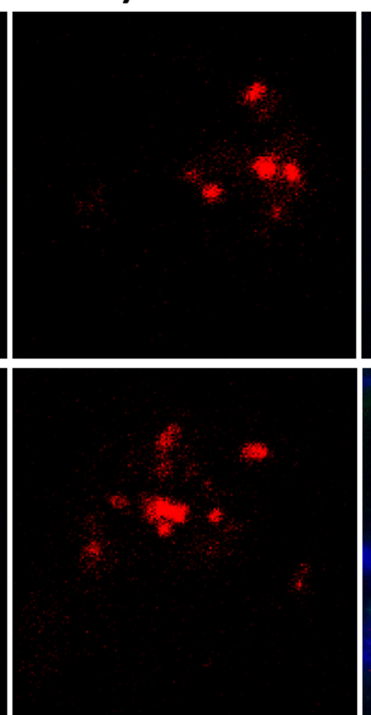

Merged

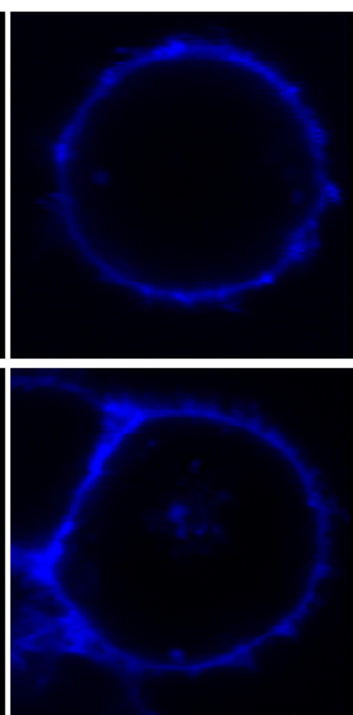

Figure I Cellular uptake of SiNCs with different sizes in $\mathrm{CD}^{+}{ }^{+}$-cells. (A) Cell viability and (B) Cy5 positive-cells of CD8 ${ }^{+} \mathrm{T}$-cells after treatment with various kinds of SiNCs $(20 \mu \mathrm{g} / \mathrm{mL})$ in the presence of $1 \%$ FBS for $24 \mathrm{~h}$. cLSM images showing $(\mathbf{C})$ the uptake of SiNCs and (D) co-localization with lysosome in CD8 ${ }^{+}$T-cells. Co-localization assay was performed by staining lysosome with LysoTracker ${ }^{\circledR}$ Green DND-26 (red). The membrane was stained with CellMask ${ }^{\mathrm{TM}}$ Orange (blue). The SiNC was labeled with Cy5 (green). The merged images of the three channels demonstrated that the SiNCs were co-localized with lysosomes, as indicated with white arrows. The scale bars represent $10 \mu \mathrm{m}$. Data are expressed as mean $\pm S D(n=3) .{ }^{*} p<0.05, * * p<0.01$ and $*^{* * *} p<0.001$.

the negative charge of silanol groups at a $\mathrm{pH}$ above the isoelectric point of silica ( $\sim \mathrm{pH} 2-3)$, NC(i)-LUT showed a slightly negative $\zeta$-potential $(-3.0 \pm 0.1 \mathrm{mV})$. Moreover, the surface charges of SiNCs became more positive when more $\mathrm{NH}_{2}$ functionalization was applied. It turned from a slightly negative charge in NC(i)-LUT- $1 \% \mathrm{NH}_{2}(-2.6 \pm$ $0.3 \mathrm{mV})$ to nearly neutral in NC(i)-LUT- $2.5 \% \mathrm{NH}_{2}(0.7 \pm$ $0.2 \mathrm{mV}$ ) and became slightly positive in NC(i)-LUT-5\% $\mathrm{NH}_{2}$ $(4.0 \pm 0.5 \mathrm{mV})$. In addition, the non-ionic surfactant Tweenstabilized SiNCs also showed negative surface charges as the 
Table 2 Overview of Different Functionalized Silica Nanocapsules Regarding the Core Hydrophobicity, Surfactants and Amino Functionalization

\begin{tabular}{|c|c|c|c|c|c|c|c|}
\hline & \multicolumn{2}{|c|}{ Hydrophobic Core, NC(o) } & \multicolumn{2}{|c|}{ Hydrophilic Core, NC(i) } & \multicolumn{3}{|c|}{ Hydrophilic Core + Amino Functionalization } \\
\hline & NC(o)-CTAC & NC(o)-LUT & NC(i)-CTAC & NC(i)-LUT & $\begin{array}{l}\mathbf{N C ( i ) - L U T ~} \\
-1 \% \mathrm{NH}_{2}\end{array}$ & $\begin{array}{l}\text { NC(i)-LUT } \\
-2.5 \% \mathrm{NH}_{2}\end{array}$ & $\begin{array}{l}\text { NC(i)-LUT } \\
-5 \% \mathrm{NH}_{2}\end{array}$ \\
\hline$D_{\mathrm{h}}\left(\mathrm{H}_{2} \mathrm{O}\right) / \mathrm{nm}$ & $162 \pm 81$ & $157 \pm 69$ & $104 \pm 48$ & $115 \pm 55$ & $128 \pm 16$ & $204 \pm 95$ & $130 \pm 45$ \\
\hline$\zeta$-potential $\left(\mathrm{H}_{2} \mathrm{O}\right) / \mathrm{mV}$ & $12.2 \pm 0.5$ & $0.1 \pm 0.1$ & $13.0 \pm 0.2$ & $-3.0 \pm 0.1$ & $-2.6 \pm 0.3$ & $0.7 \pm 0.2$ & $4.0 \pm 0.5$ \\
\hline
\end{tabular}

LUT group $(-19.6 \pm 1.2 \mathrm{mV}$ for $\mathrm{NC}(\mathrm{i})-\mathrm{T} 20$ and $-11.1 \pm 0.6$ $\mathrm{mV}$ for NC(i)-T80). However, the NC(i)-T20 and NC(i)-T80 were not used for further cellular uptake studies because of their large sizes $(2-6 \mu \mathrm{m})$. TEM micrographs demonstrate the morphology of the NCs (Figure S1, Supporting Information) indicating a homogeneous capsule formation, which were subsequently transferred to LUT-stabilized and additionally amino-functionalized NCs.

After $24 \mathrm{~h}$ of exposure, the cellular uptake of SiNCs with different cores and different surface charges in $\mathrm{CD}^{+}$ T-cells was investigated, as shown in Figure 2. We observed an increased toxicity in a dose-dependent manner

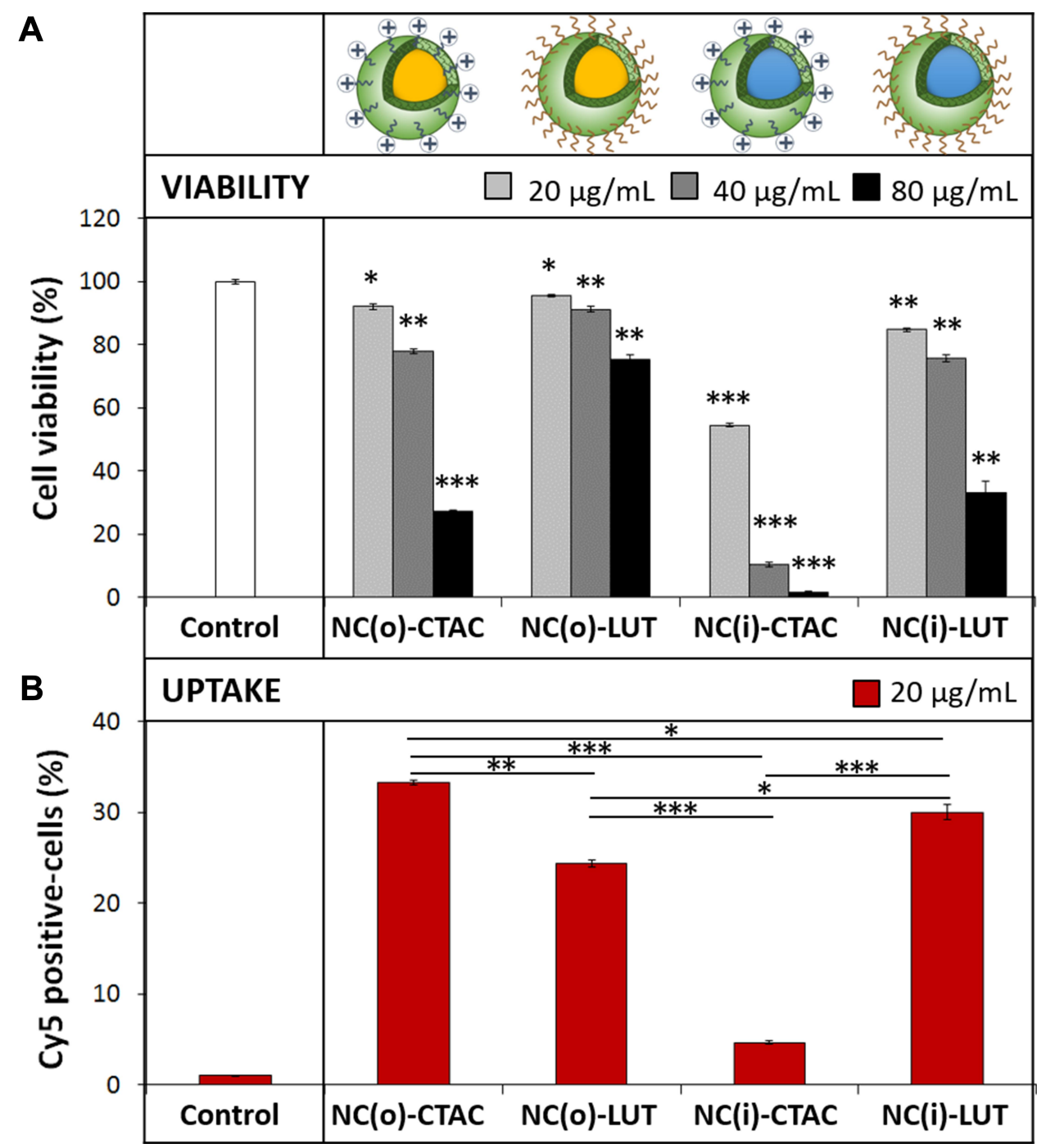

Figure 2 Cellular uptake study of SiNCs with different cores and different surfactants in CD8 ${ }^{+}$T-cells. (A) Cell viability and (B) Cy5 positive-cells of CD8 ${ }^{+}$T-cells after treatment with different SiNCs in the presence of I\% FBS for $24 \mathrm{~h}$. Data are expressed as mean \pm SD $(\mathrm{n}=3)$. $* p<0.05$, **p<0.0I and $* * * p<0.00 \mathrm{I}$. Abbreviations: o, hydrophobic core; i, hydrophilic core; CTAC, cetyltrimethylammonium chloride; LUT, Lutensol AT50. 
for all capsules (Figure 2A). In general, LUT stabilized SiNCs were less toxic to the cells compared to the CTAC stabilized SiNCs. All SiNCs showed a similar cellular binding (Figure 2B), except for NC(i)-CTAC due to its high toxicity. It seems that the uptake level is strongly related to toxicity. As shown in the case of smaller size SiNCs $(<100 \mathrm{~nm})$ in Figure 1 and NC(i)-CTAC in Figure 2. Thus, due to their high toxicity, the living cells were decreased. The cells that take up these SiNCs tended to not survive leading to the decrease in the total uptake cells.

To follow the cellular uptake, NC(o)-LUT covalently functionalized with FITC were incubated with Jurkat T-cells for different time points (Figure S3, Supporting Information). Via flow cytometry and cLSM, we could detect a time-dependent uptake process starting already after $4 \mathrm{~h}$.

\section{The Effect of Surface Functionalization}

Amino functionalization is one of the most common ways for surface modification of drug nanocarriers. Further investigations on the effect of amino functionalization of SiNCs on cellular uptake were carried out in $\mathrm{CD}^{+}$T-cells (Figure 3). After $24 \mathrm{~h}$, a dose-dependent toxicity was observed. At the same concentration, SiNCs with increasing amounts of amino groups did not affect the cell viability compared to unfunctionalized NCs. Overall, the amount of $\mathrm{Cy} 5$ positive-cells were slightly decreased when SiNCs with a higher number of $\mathrm{NH}_{2}$ functionalization were applied to the cells. In general, the surface functionalization is one of the major parameters contributory to toxicity as functional groups on the nanocapsules surface can directly interact with the cells and their

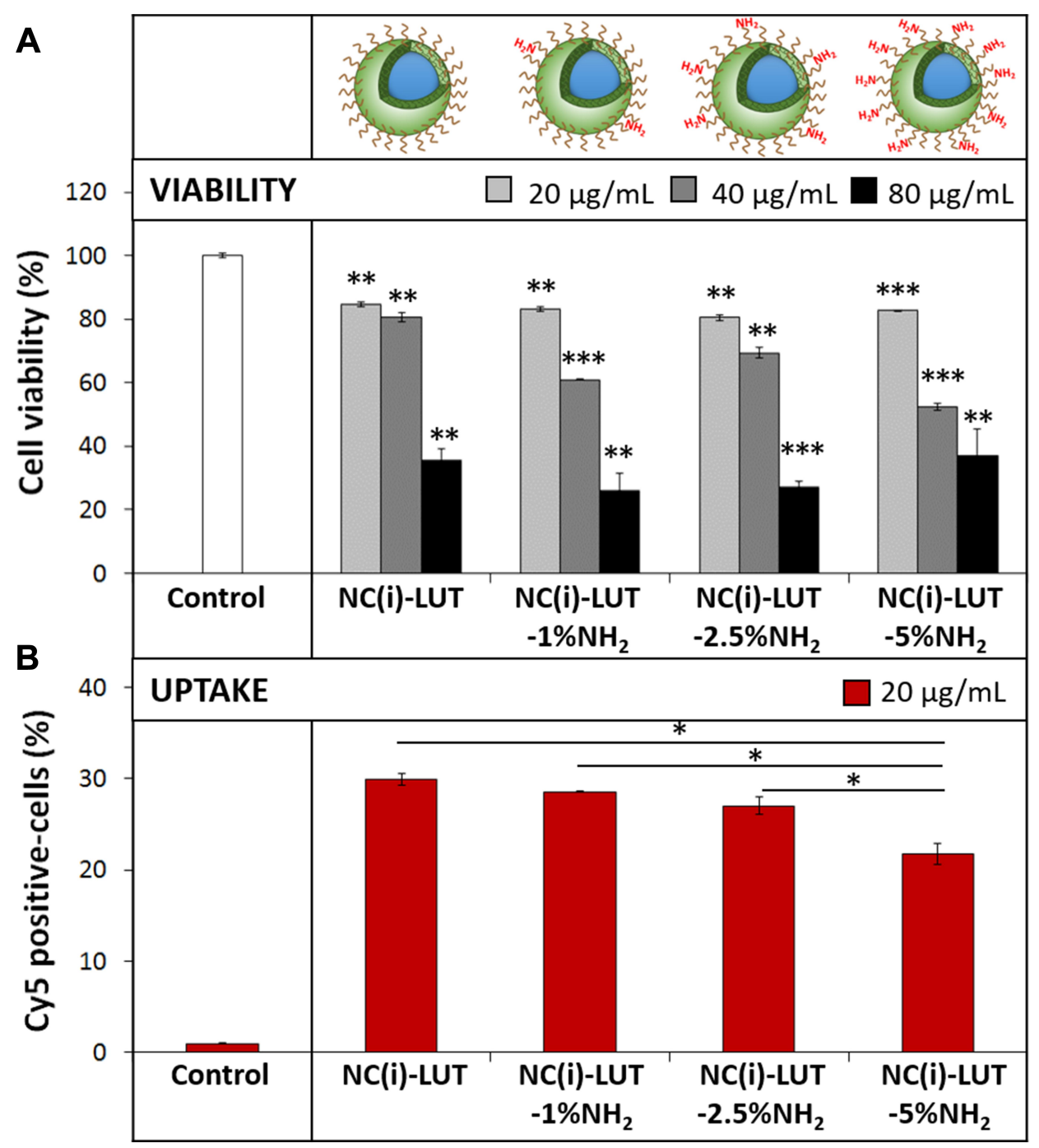

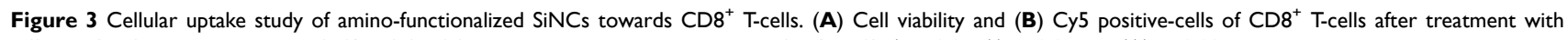
different SiNCs in the presence of I\% FBS for $24 \mathrm{~h}$. Data are expressed as mean \pm SD $(\mathrm{n}=3)$. $* p<0.05$, $* * p<0.01$ and $* * * p<0.001$.

Abbreviations: i, hydrophilic core; LUT, Lutensol AT50. 
compartments. $^{35}$ However, the amino functionalization had no impact on toxicity.

\section{The Effect of Protein Corona and Serum Concentrations}

After injection into the body, the nanocarriers will travel along the bloodstream and face numerous components in the blood such as proteins. Due to their attractive surface charges, the proteins can be electrostatically adsorbed on the surface of nanocarriers, which is known as protein corona, hereby changing the nanocarriers' surface properties, covering the targeting moieties and finally impacting

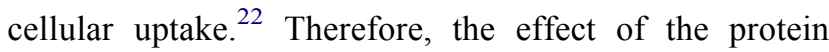
corona was studied in terms of toxicity, uptake and protein pattern as well as protein identification to understand the uptake behavior, as shown in Figures 4 and 5. SiNCs were incubated with human serum (HS) prior to adding them to $\mathrm{CD}^{+}$T-cells in medium containing different percentages of HS. The results indicate that the protein corona reduced the toxicity for all SiNCs compared to uncoated NCs (Figure 4A). It was also found that the medium containing a higher percentage of HS contributed to enhancement of cell viability similar to previous study. ${ }^{25}$ However, the uptake was dramatically decreased in all cases compared to the uncoated NCs, together with increasing of $\% \mathrm{HS}$ in the medium, especially at $10 \% \mathrm{HS}$ (Figure 4B). These results suggest that the uptake of SiNCs in $\mathrm{CD}^{+}$T-cells was inhibited by the adsorbed protein forming protein corona, which can be observed from the pre-coated NCs. In addition, the different concentrations of serum might result in differences in corona composition leading to a decreased uptake with increasing

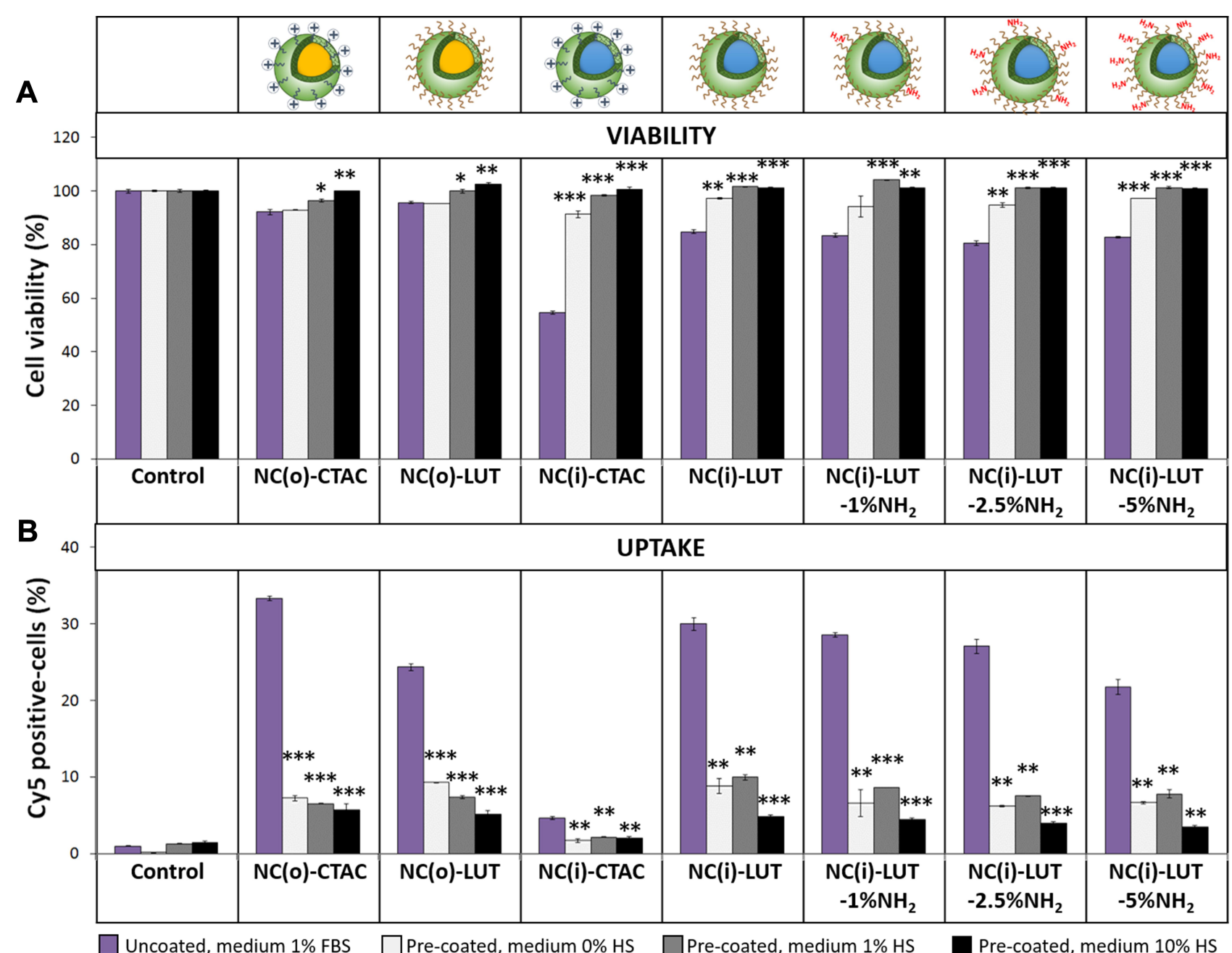

Figure 4 Protein corona study of different SiNCs $(20 \mu \mathrm{g} / \mathrm{mL})$ towards CD8 ${ }^{+}$T-cells. (A) Cell viability and (B) Cy5 positive-cells of CD8 ${ }^{+}$T-cells after treatment with I) uncoated SiNCs in the presence of I\% FBS, 2) HS pre-coated SiNCs in the presence of $0 \%$ HS for $6 \mathrm{~h}$. After that, the HS was added to obtain I\% HS, 3) HS pre-coated SiNCs in the presence of I\% HS, and 4) HS pre-coated SiNCs in the presence of I0\% HS. Data are expressed as mean \pm SD $(\mathrm{n}=3$ ). $* p<0.05$, $* * p<0.0 \mathrm{I}$ and $* * * p<0.00 \mathrm{I}$. Abbreviations: o, hydrophobic core; i, hydrophilic core; CTAC, cetyltrimethylammonium chloride; LUT, Lutensol AT50; FBS, fetal bovine serum; HS, human serum. 
A

M OOOOOO

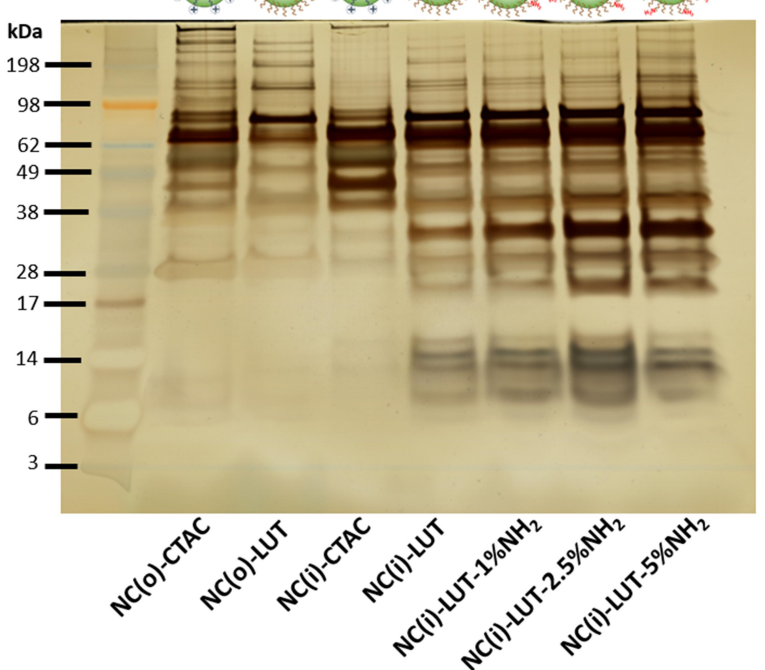

c O OOO OOO

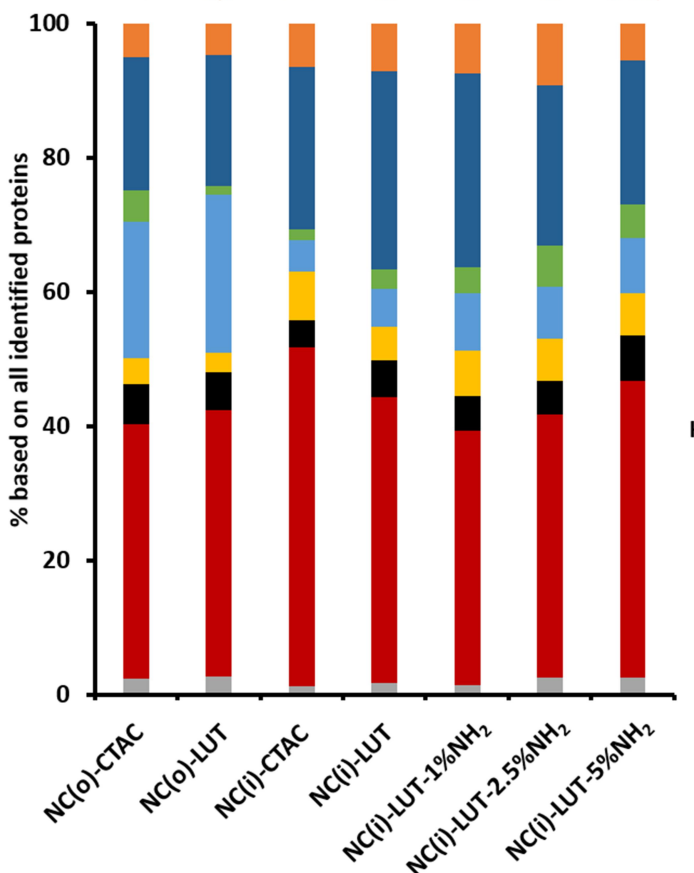

Tissue Leakage

- Serum albumin

Immunoglobulins

- Coagulation
B

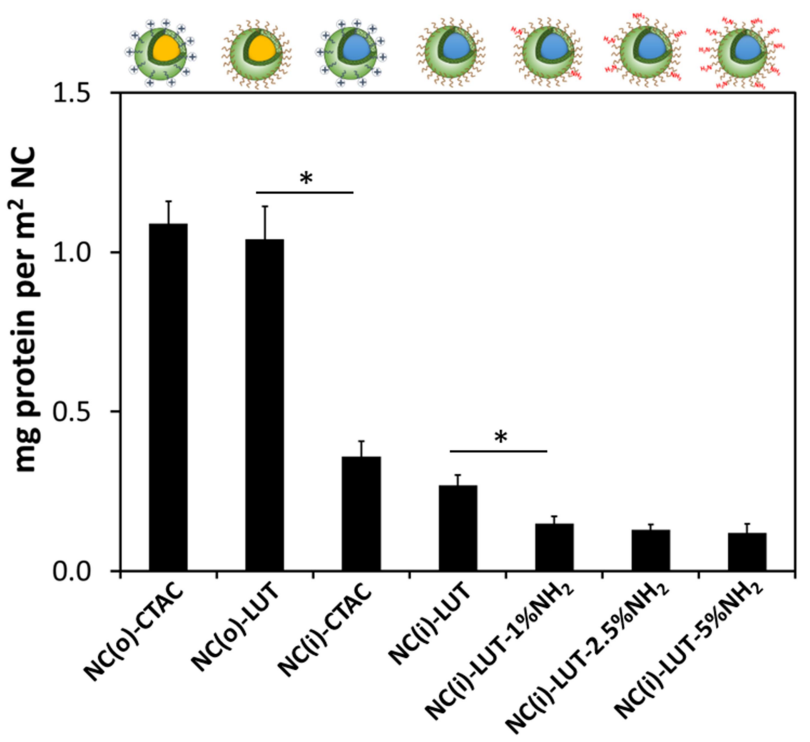

D

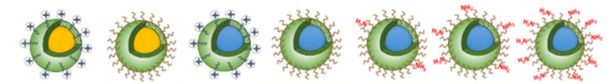

Adenylate kinase 9

Apolipoprotein A-I

Apolipoprotein A-IV

Apolipoprotein B-100

Apolipoprotein E

Clusterin

Coagulation factor $\mathrm{XI}$

Coagulation factor XII

Complement C3

Histidine-rich glycoprotein

Ig gamma-2

Ig kappa

Ig mu
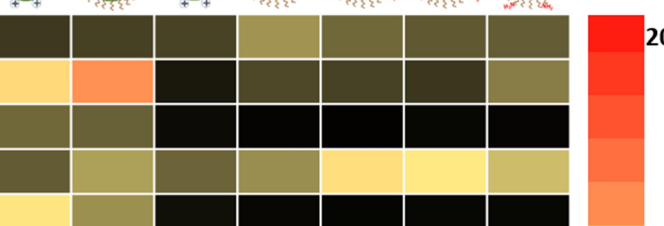

Inter-alpha-trypsin $\mathrm{H} 4$

Kininogen-1

LPS-binding protein

Plasminogen

Platelet factor 4

Prothrombin

Selenoprotein P

Serum albumin

Vitronectin

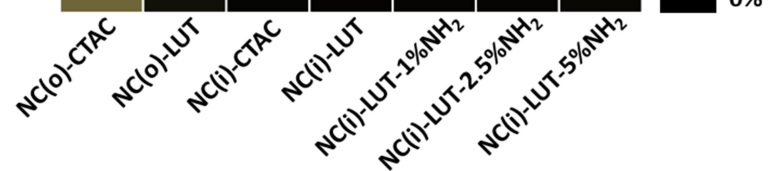

Figure 5 Protein corona analysis of SiNCs (surface area $=0.05 \mathrm{~m}^{2}$ ) incubated with human serum (HS). (A) Hard corona pattern analyzed by SDS-PAGE with I.5 $\mu \mathrm{g}$ total protein loading. (B) Protein adsorbed amount per $\mathrm{m}^{2}$ SiNC. LC-MS analysis showing (C) protein annotation classified based on their biological function and (D) heat map illustrating the most abundant corona proteins (amount $>1 \%$ based on all identified proteins). The color gradients are non-linear to facilitate visualization of low amount proteins. Data are expressed as mean $\pm S D(n=3) . * p<0.05$.

Abbreviations: o, hydrophobic core; i, hydrophilic core; CTAC, cetyltrimethylammonium chloride; LUT, Lutensol AT50. 
serum concentration. For gold nanoparticles, it was found that the corona inhibited caveolae-mediated endocytosis resulting in decreased uptake in human epidermal keratinocytes. $^{40}$

After forming the protein corona, the physicochemical properties of SiNCs were analyzed. Overall, the hydrodynamic size increased for all SiNCs (Table S1, Supporting Information). The $\zeta$-potential after corona was about -20 $\mathrm{mV}$ for NCs as the surface was saturated with a high amount of adsorbed proteins (Table S1, Supporting Information). There were no significant differences in the surface charges after corona formation of the various nanoparticles, which was also reported in the literature. ${ }^{41}$

In order to understand the reason for the inhibited cellular uptake of protein-coated NCs, the composition of protein corona was further analyzed. The corona pre-formed SiNCs were centrifuged to remove the loosely bound proteins, which comprise the "soft corona". The proteins adsorbed on SiNC surfaces were desorbed and subsequently separated by SDSPAGE (Figure 5A). The silver-stained gel revealed different "hard corona" patterns for the 7 different SiNCs. Some small proteins in the size of 6-16 kDa were only found in the corona of $\mathrm{NC}(\mathrm{i})$-LUT with and without $\mathrm{NH}_{2}$-functionalization. These results indicate that the physicochemical properties of the NCs had a strong effect on corona composition. Furthermore, the total protein amount adsorbed per $\mathrm{m}^{2} \mathrm{SiNC}$ was calculated (Figure 5B). The $\mathrm{NC}(\mathrm{o})$ had a higher amount of protein adsorbed on the surface compared to NC(i). In our previous work we showed by NMR that the oil-water exchange results in further hydrolysis of the alkoxysilanes. ${ }^{42}$ Therefore, this process has an influence on the silica network. Based on this, we assume that $\mathrm{NC}(\mathrm{i})$ are more hydrophilic compared to $\mathrm{NC}(\mathrm{o})$, which affects the adsorption of blood proteins. In literature, it was shown that a hydrophobic surface of nanoparticles also results in an increased adsorption of proteins compared to a hydrophilic surface. ${ }^{42}$ Among the hydrophilic core, NC(i)-CTAC had the highest amount of protein adsorbed. It can be observed that the protein amount was decreased with increasing $\mathrm{NH}_{2}$-functionalization.

In "hard corona", proteins were analyzed by LC-MS. Proteins involved in the coagulation cascade (e.g. histidinerich glycoprotein, kininogen, plasminogen, and vitronectin) were the dominant protein group for all SiNCs (Figure 5C and D). Similar to literature reports, ${ }^{22,41,43,44}$ histidine-rich glycoprotein was strongly enriched for all SiNCs, especially in LUT-stabilized SiNCs $(>35 \%)$ while in CTAC-stabilized ones the amount was slightly lower $15-20 \%$ (Figure 5D). In addition, serum albumin, which is the most abundant protein in the blood serum, was also identified in the protein corona for all SiNCs. As discovered by other researchers, ${ }^{22,41-44}$ apolipoproteins were identified in the protein corona of all SiNCs, especially apolipoprotein B-100. Apolipoproteins play a major role in lipid and cholesterol transportation and could facilitate intracellular trafficking. ${ }^{45,46}$ Disparate corona compositions were observed between hydrophobic and hydrophilic cores SiNCs. Apolipoprotein A-I and apolipoprotein E were enriched in hydrophobic core SiNCs, whereas insulinlike growth factor was enriched in hydrophilic core SiNCs. Significant enrichment of kininogen was detected for CTACstabilized SiNCs, while a notable amount of plasminogen was detected for LUT-stabilized NCs. Some of these dominant proteins detected in the protein corona might be responsible to either facilitate or inhibit the uptake, which needs to be further investigated. This is clearly a work that needs to be done not only for SiNCs and is the focus of further work.

\section{The Effect on Cytokine Secretion}

Besides toxicity, an immunological effect in a sizedependent manner was found for SiNPs in immune cells including monocytes and macrophages. It was indicated that nano-sized particles caused a significant increase in pro-inflammatory secretion such as tumor necrosis factoralpha (TNF- $\alpha$ ) compared to sub-micron and micron sized particles. ${ }^{17}$ Therefore, we further investigated the effect on cytokine secretion of $\mathrm{CD}^{+}$T-cells after treatment with different SiNCs (Figure 6).

Cytokine secretion assay was performed using the enzymelinked immunosorbent assay (ELISA) for determining the concentrations of interferon-gamma (IFN- $\gamma$ ) (Figure 6A), interleukin-2 (IL-2) (Figure 6B), and tumor necrosis factorbeta (TNF- $\beta$ ) (Figure 6C). It was found that LUT-stabilized SiNCs did not affect IFN- $\gamma$ and TNF- $\beta$ secretions, but slightly decreased the IL-2 production. Whereas, CTAC-stabilized SiNCs caused a decrease in TNF- $\beta$ production and slightly decreased the IL- 2 production but did not affect IFN- $\gamma$ secretions. This indicates the better biocompatibility of the LUTstabilized SiNCs compared to CTAC-stabilized SiNCs. Even the concentration of SiNCs $(10 \mu \mathrm{g} / \mathrm{mL})$ used in this experiment did not cause toxicity to the cells as indicated by flow cytometer results. This emphasizes the high sensitivity of T-cells in terms of not only toxicity, but also pro-inflammatory effects that should be carefully considered.

\section{Conclusion}

It was shown that silica nanocapsules are highly suitable for uptake in difficult to be transfected T-cells. The 

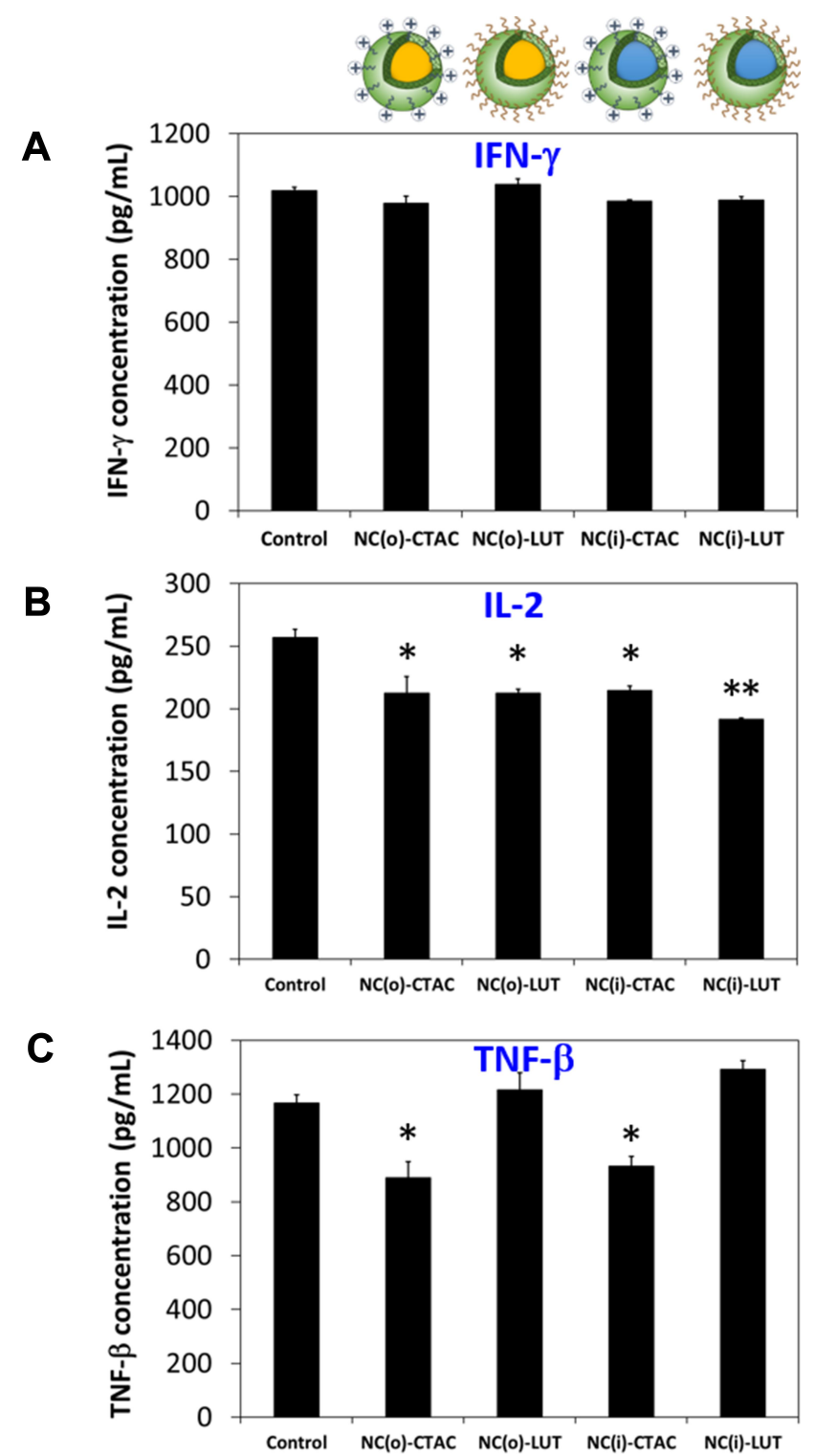

Figure 6 Cytokine secretion assay of $\mathrm{CD} 8^{+}$T-cells after treatment with SiNCs (10 $\mu \mathrm{g} / \mathrm{mL}$ ) in the presence of $1 \% \mathrm{FBS}$ for $24 \mathrm{~h}$. After collection of supernatants, ELISA assay was performed for quantification of (A) IFN- $\gamma$, (B) IL-2, and (C) TNF- $\beta$ according to the manufacturers' instruction. Data are expressed as mean \pm SD $(n=3) . * p<0.05, * * p<0.01$.

different physicochemical properties of silica nanocapsules (SiNCs) led to different toxicities and also affected the uptake behavior in T-cells. The major impact on cellular uptake and viability was found to be dose- and sizedependent. Smaller sized SiNCs than $100 \mathrm{~nm}$ caused significant toxicity to the cells, which is probably due to ROS-mediated toxicity. The toxicity of hydrophobic core SiNCs was comparable to the hydrophilic core SiNCs. Depending on the payload, the core can be chosen. The effect of different surface charges on cellular uptake was observed, showing the positive charges of CTAC- stabilized SiNCs decreased the cell viability as well as the uptake compared to closely neutral charged LUTstabilized SiNCs. In addition, an increasing number of amino groups on SiNC surface slightly decreased the uptake but did not affect the viable cells. Furthermore, the protein corona study revealed that both protein corona and medium containing serum were able to lower the toxicity of SiNCs, leading to improved viability; however, these conditions inhibited uptake. Therefore, the concentration of serum in culture condition should be optimized carefully in order to facilitate the uptake, but still keep the cells alive. These findings suggest the appropriate criteria for SiNCs designing based on their physicochemical properties which results in a major impact on cellular uptake and toxicity in $\mathrm{CD}^{+}$T-cells. In general, T-cells do not take up foreign particles easily and they are highly sensitive and not resistant in terms of toxicity. ${ }^{18}$ Therefore, the delivery system that is suitable for T-cell treatment has to meet the safety criteria with the ability to protect and deliver the payload without causing toxicity as well as proinflammatory effects. For SiNC, it is easy to manipulate the structures and surface properties based on these findings in order to avoid toxicity and favor uptake. Therefore, SiNCs are a promising delivery system, which can be applied as a nanocarrier in T-cell immunotherapy.

\section{Acknowledgment}

This paper is partially based on the doctoral dissertation of R.T. published at the Faculty of Biology, Johannes Gutenberg University (Mainz, Germany) which has been carried out at the Max Planck Institute for Polymer Research (Mainz, Germany). ${ }^{47}$ R.T. was supported by the National Nanotechnology Center, Thailand, and the Royal Thai government scholarship. The work was supported by the Deutsche Forschungsgemeinschaft (DFG) by the CRC 1066 ("Sonderforschungsbereich" SFB 1066). We acknowledge Milagro Mottola for the amino functionalization experiments and Jorge Pereira for cellular uptake experiments in Jurkat T-cells.

\section{Disclosure}

Raweewan Thiramanas reports grants from Royal Thai Government Scholarship, during the conduct of the study. Volker Mailänder reports grants from Deutsche Forschungsgemeinschaft (DFG). The authors report no other potential conflicts of interest in this work. 


\section{References}

1. Cohen JE, Merims S, Frank S, Engelstein R, Peretz T, Lotem M. Adoptive cell therapy: past, present and future. Immunotherapy. 2017;9(2):183-196. doi:10.2217/imt-2016-0112

2. Wang M, Yin B, Wang HY, Wang R-F. Current advances in T-cell-based cancer immunotherapy. Immunotherapy. 2014;6(12):1265-1278. doi:10.2217/imt.14.86

3. Perica K, Varela JC, Oelke M, Schneck J. Adoptive T cell immunotherapy for cancer. Rambam Maimonides Med J. 2015;6(1):e0004. doi:10.5041/RMMJ.10179

4. Sathyanarayanan V, Neelapu SS. Cancer immunotherapy: strategies for personalization and combinatorial approaches. Mol Oncol. 2015;9 (10):2043-2053. doi:10.1016/j.molonc.2015.10.009

5. Baruch EN, Berg AL, Besser MJ, Schachter J, Markel G. Adoptive T cell therapy: an overview of obstacles and opportunities. Cancer. 2017;123(S11):2154-2162. doi:10.1002/cncr.30491

6. Li AV, Moon JJ, Abraham W, et al. Generation of effector memory T cell-based mucosal and systemic immunity with pulmonary nanoparticle vaccination. Sci Transl Med. 2013;5(204):204ra130. doi:10.1126/scitranslmed.3006516

7. Zitvogel L, Kroemer G. Targeting PD-1/PD-L1 interactions for cancer immunotherapy. Oncoimmunology. 2012;1(8):1223-1225. doi:10.4161/onci.21335

8. Frick SU, Domogalla MP, Baier G, et al. Interleukin-2 functionalized nanocapsules for T cell-based immunotherapy. ACS Nano. 2016;10 (10):9216-9226. doi:10.1021/acsnano.5b07973

9. Schmid D, Park CG, Hartl CA, et al. T cell-targeting nanoparticles focus delivery of immunotherapy to improve antitumor immunity. Nat Commun. 2017;8(1):1747. doi:10.1038/s41467-017-01830-8

10. Li SY, Liu Y, Xu CF, et al. Restoring anti-tumor functions of $\mathrm{T}$ cells via nanoparticle-mediated immune checkpoint modulation. $J$ Control Release. 2016;231:17-28. doi:10.1016/j.jconrel.2016.01.044

11. Stromnes IM, Blattman JN, Tan X, Jeevanjee S, Gu H, Greenberg PD. Abrogating Cbl-b in effector CD8(+) T cells improves the efficacy of adoptive therapy of leukemia in mice. $J$ Clin Invest. 2010;120(10):3722-3734. doi:10.1172/JCI41991

12. Ligtenberg MA, Pico de Coana Y, Shmushkovich T, et al. Selfdelivering RNAi targeting PD-1 improves tumor-specific T cell functionality for adoptive cell therapy of malignant melanoma. Mol Ther. 2018;26(6):1482-1493. doi:10.1016/j.ymthe.2018.04.015

13. Iwamura K, Kato T, Miyahara Y, et al. siRNA-mediated silencing of PD-1 ligands enhances tumor-specific human T-cell effector functions. Gene Ther. 2012;19(10):959-966. doi:10.1038/gt.2011.185

14. Ding C, Tong L, Feng J, Fu J. Recent advances in stimuli-responsive release function drug delivery systems for tumor treatment. Molecules. 2016;21(12):1715. doi:10.3390/molecules21121715

15. Mohanraj V, Chen Y. Nanoparticles-a review. Trop J Pharm Res. 2006;5(1):561-573.

16. Zhang Y, Hsu BY, Ren C, Li X, Wang J. Silica-based nanocapsules: synthesis, structure control and biomedical applications. Chem Soc Rev. 2015;44(1):315-335. doi:10.1039/C4CS00199K

17. Murugadoss S, Lison D, Godderis L, et al. Toxicology of silica nanoparticles: an update. Arch Toxicol. 2017;91(9):2967-3010. doi:10.1007/s00204-017-1993-y

18. Freeley M, Long A. Advances in siRNA delivery to T-cells: potential clinical applications for inflammatory disease, cancer and infection. Biochem J. 2013;455(2):133-147. doi:10.1042/BJ20130950

19. Mendoza A, Torres-Hernandez JA, Ault JG, Pedersen-Lane JH, Gao D, Lawrence DA. Silica nanoparticles induce oxidative stress and inflammation of human peripheral blood mononuclear cells. Cell Stress Chaperones. 2014;19(6):777-790. doi:10.1007/s12192-0140502-y

20. Vis B, Hewitt RE, Faria N, et al. Non-functionalized ultrasmall silica nanoparticles directly and size-selectively activate T cells. ACS Nano. 2018;12(11):10843-10854. doi:10.1021/acsnano.8b03363
21. Napierska D, Thomassen LC, Lison D, Martens JA, Hoet PH. The nanosilica hazard: another variable entity. Part Fibre Toxicol. 2010;7 (1):39. doi:10.1186/1743-8977-7-39

22. Lundqvist M, Augustsson C, Lilja M, et al. The nanoparticle protein corona formed in human blood or human blood fractions. PLoS One. 2017;12(4):e0175871. doi:10.1371/journal.pone. 0175871

23. Hofmann D, Tenzer S, Bannwarth MB, et al. Mass spectrometry and imaging analysis of nanoparticle-containing vesicles provide a mechanistic insight into cellular trafficking. ACS Nano. 2014;8 (10):10077-10088. doi:10.1021/nn502754c

24. Schöttler S, Becker G, Winzen S, et al. Protein adsorption is required for stealth effect of poly(ethylene glycol)- and poly(phosphoester)-coated nanocarriers. Nature Nanotech. 2016;11(4):372-377. doi:10.1038/ nnano. 2015.330

25. Silva JC, Gorenstein MV, Li GZ, Vissers JP, Geromanos SJ. Absolute quantification of proteins by LCMSE: a virtue of parallel MS acquisition. Mol Cell Proteomics. 2006;5(1):144-156. doi:10.1074/ mcp.M500230-MCP200

26. Jiang S, Lv L, Li Q, Wang J, Landfester K, Crespy D. Tailoring nanoarchitectonics to control the release profile of payloads. Nanoscale. 2016;8(22):11511-11517. doi:10.1039/C6NR00917D

27. Philipse AP, Van Bruggen MP, Pathmamanoharan C. Magnetic silica dispersions: preparation and stability of surface-modified silica particles with a magnetic core. Langmuir. 1994;10(1):92-99. doi:10.1021/la00013a014

28. Hsiao I-L, Gramatke AM, Joksimovic R, Sokolowski M, Gradzielski M, Haase A. Size and cell type dependent uptake of silica nanoparticles. J Nanomed Nanotechnol. 2014;5(6):1.

29. Li Y, Sun L, Jin M, et al. Size-dependent cytotoxicity of amorphous silica nanoparticles in human hepatoma HepG2 cells. Toxicol Vitro. 2011;25(7):1343-1352. doi:10.1016/j.tiv.2011.05.003

30. Nabeshi H, Yoshikawa T, Matsuyama K, et al. Size-dependent cytotoxic effects of amorphous silica nanoparticles on Langerhans cells. Pharmazie. 2010;65(3):199-201.

31. Napierska D, Thomassen LC, Rabolli V, et al. Size-dependent cytotoxicity of monodisperse silica nanoparticles in human endothelial cells. Small. 2009;5(7):846-853. doi:10.1002/smll.200800461

32. Yildirimer L, Thanh NT, Loizidou M, Seifalian AM. Toxicology and clinical potential of nanoparticles. Nano Today. 2011;6(6):585-607. doi:10.1016/j.nantod.2011.10.001

33. Bakand S, Hayes A. Toxicological considerations, toxicity assessment, and risk management of inhaled nanoparticles. Int J Mol Sci. 2016;17(6):929. doi:10.3390/ijms17060929

34. Huang YW, Cambre M, Lee HJ. The toxicity of nanoparticles depends on multiple molecular and physicochemical mechanisms. Int J Mol Sci. 2017;18(12):2702. doi:10.3390/ijms18122702

35. Buzea C, Pacheco II, Robbie K. Nanomaterials and nanoparticles: sources and toxicity. Biointerphases. 2007;2(4):MR17-MR71. doi:10.1116/1.2815690

36. Kipen HM, Laskin DL. Smaller is not always better: nanotechnology yields nanotoxicology. Am J Physiol Lung Cell Mol Physiol. 2005;289(5):L696-L697. doi:10.1152/ajplung.00277.2005

37. Nabeshi H, Yoshikawa T, Matsuyama K, et al. Amorphous nanosilica induce endocytosis-dependent ROS generation and DNA damage in human keratinocytes. Part Fibre Toxicol. 2011;8(1):1. doi:10.1186/ 1743-8977-8-1

38. Accomasso L, Gallina C, Turinetto V, Giachino C. Stem cell tracking with nanoparticles for regenerative medicine purposes: an overview. Stem Cells Int. 2016;2016:7920358. doi:10.1155/2016/7920358

39. Betzer O, Shilo M, Opochinsky R, et al. The effect of nanoparticle size on the ability to cross the blood-brain barrier: an in vivo study. Nanomedicine. 2017;12(13):1533-1546. doi:10.2217/nnm-20170022

40. Li Y, Monteiro-Riviere NA. Mechanisms of cell uptake, inflammatory potential and protein corona effects with gold nanoparticles. Nanomedicine. 2016;11(24):3185-3203. doi:10.2217/nnm-2016-0303 
41. Mirshafiee V, Kim R, Park S, Mahmoudi M, Kraft ML. Impact of protein pre-coating on the protein corona composition and nanoparticle cellular uptake. Biomaterials. 2016;75:295-304. doi:10.1016/j. biomaterials.2015.10.019

42. Nguyen VH, Lee BJ. Protein corona: a new approach for nanomedicine design. Int J Nanomedicine. 2017;12:3137-3151. doi:10.2147/ IJN.S129300

43. Mirshafiee V, Kim R, Mahmoudi M, Kraft ML. The importance of selecting a proper biological milieu for protein corona analysis in vitro: human plasma versus human serum. Int $J$ Biochem Cell Biol. 2016;75:188-195. doi:10.1016/j.biocel.2015.11.019

44. Kurtz-Chalot A, Villiers C, Pourchez J, et al. Impact of silica nanoparticle surface chemistry on protein corona formation and consequential interactions with biological cells. Mater Sci Eng C Mater Biol Appl. 2017;75:16-24. doi:10.1016/j.msec.2017.02.028
45. Clemments AM, Botella P, Landry CC. Protein adsorption from biofluids on silica nanoparticles: corona analysis as a function of particle diameter and porosity. ACS Appl Mater Interfaces. 2015;7 (39):21682-21689. doi:10.1021/acsami.5b07631

46. Mortensen NP, Hurst GB, Wang W, Foster CM, Nallathamby PD, Retterer ST. Dynamic development of the protein corona on silica nanoparticles: composition and role in toxicity. Nanoscale. 2013;5 (14):6372-6380. doi:10.1039/c3nr33280b

47. Thiramanas R, 2019. Nanocapsules for uptake, release and sensing in cells. Doctoral dissertation, Johannes Gutenberg-Universität Mainz.

\section{Publish your work in this journal}

The International Journal of Nanomedicine is an international, peerreviewed journal focusing on the application of nanotechnology in diagnostics, therapeutics, and drug delivery systems throughout the biomedical field. This journal is indexed on PubMed Central, MedLine, CAS, SciSearch ${ }^{\mathbb{R}}$, Current Contents ${ }^{\mathbb{R}} /$ Clinical Medicine, $^{2}$
Journal Citation Reports/Science Edition, EMBase, Scopus and the Elsevier Bibliographic databases. The manuscript management system is completely online and includes a very quick and fair peer-review system, which is all easy to use. Visit http://www.dovepress.com/ testimonials.php to read real quotes from published authors. 